\title{
Preludium na gród, zamek i klasztor. Exemplum Polski Centralnej
}

\section{Prelude on stronghold, castle and monastery. A Central Poland exemplum}

Zarys treści. Artykuł zawiera krótkie naświetlenie relacji pomiędzy grodami, zamkami, klasztorami i miastami Polski Centralnej od okresu plemiennego do państwa ostatnich Piastów, szczególnie w aspekcie kontynuacji i dyskontynuacji chronologicznej, a także relacji pomiędzy poszczególnymi typami struktur osadniczych. Krajobraz kulturowy zdeterminowany najpierw przez plemienne, a potem już piastowskie grody zarysował pewną siatkę miejsc ważnych, z pozostającą poza klasyfikacją, autentycznie centralną Łęczycą tumską. Wyraźne wahnięcie przyniosło najpierw opanowane terenu Polski Centralnej przez „Polan”, a potem stworzenie sieci ośrodków kasztelańskich, wytyczających regionalne centra polityczne i osadnicze. Funkcjonowanie ich zostało naruszone przez przemiany wieku XIII, a ostatecznie zanikły w XIV stuleciu, gdy na miejscu kilku takich grodów zbudowano także państwowe zamki. Przemiana ta ustaliła generalnie obraz centrów i innych struktur osadniczych regionu, czytelnych aż do końca Rzeczypospolitej Szlacheckiej.

Stowa kluczowe: gród, zamek, klasztor, dwór obronny, miasto, Polska Centralna.

Historyczna Polska Centralna, czyli region ulokowany między właściwą Wielkopolską od zachodu i Mazowszem od wschodu, pomiędzy Kujawami od północy i Małopolską od południa, z racji swego niewielkiego obszaru i wieloznacznej „przejściowości” może być traktowany jako dobry poligon badawczy dla poznawania wieków średnich. W przekonaniu tym nawiązuję do znanych tez Jerzego Strzelczyka o peryferyczności wczesnośredniowiecznej Polski w Europie (Strzelczyk 2004, s. 225), przeniesionych przez Jerzego Sikorę (2009, s. 11) właśnie na interesujący nas teren i odniesionych do wczesnego średniowiecza. Tenże autor zwrócił uwagę, że mimo licznych starszych prac, począwszy od tej autorstwa 
Janiny Kamińskiej (1953), poprzez 22 tom czasopisma „Prace i Materiały Muzeum Archeologicznego i Etnograficznego w Łodzi, Seria Archeologiczna (Studia nad pradziejami 1975), do artykułu Aldony Chmielowskiej (1979, s. 35-51), wczesne średniowiecze Polski Centralnej poznane jest przez archeologów generalnie słabo (Kajzer 2003; 2007). Obserwowaną przez tego autora „białą plamę” po części zlikwidowała cytowana już monografia J. Sikory, a także opracowanie wyników nowszych badań na grodzie w Tumie pod Łęczycą (Początki Łęczycy 2014).

Dla historyka obecna Polska Centralna to dawne ziemie, księstwa, a potem już województwa łęczyckie i sieradzkie; niekiedy zaliczano do niej również półautonomiczną Wieluńszczyznę. Już w późnym średniowieczu był to najbardziej na wschód i południe wysunięty fragment Prowincji Wielkopolskiej. Identyfikowanie go z terenem współczesnego województwa łódzkiego jest tylko po części prawdziwe, gdyż obecny twór jest nieco większy, zaś obie historyczne ziemie zajmowały w XIV-XVIII wieku obszar liczący około $15780 \mathrm{~km}^{2}$. Dla wczesnego średniowiecza tak dokładne określenie granic i wyliczenie powierzchni terenu nie ma wielkiego sensu i dlatego zakładam, że obserwowane w tym tekście zjawiska będę badać w granicach czytelnie określonych, a więc już późnośredniowiecznych.

Wspomnieć jeszcze wypada, że interesujący nas teren znajdował się także w specyficznym kontekście geograficznym, bowiem na pograniczu dwóch wielkich stref krajobrazowych: północnej - nizinnej, gdzie znajdowało się Łęczyckie, południowej zaś wyżynnej, która zajmowała połowę Sieradzkiego i całe Wieluńskie. Geomorfolodzy dzielą go na mniejsze jednostki, które mają tu drugorzędne znaczenie, ważna jest tylko „graniczność” opisywanego regionu, leżącego pomiędzy „północą a południem”, jak kiedyś zatytułowano tom zawierający prace o archeologicznej i historycznej specyfice regionów sieradzkiego i wieluńskiego (Między pótnocą a potudniem 1993).

Pamiętając o tytule tego tekstu łatwo przewidzieć, że będzie on składać się z kilku części, z których pierwsza poświęcona zostanie wczesnośredniowiecznym grodom, druga warowniom późnośredniowiecznym, kolejne klasztorom, traktowanym nie tylko jako ważne ośrodki kultu, ale i jako swoiście pojęte centra osadnicze, wspominając też o roli organizmów miejskich, by w końcu przejść do podsumowania tych obserwacji.

Najnowsze, pełne zestawienie wczesnośredniowiecznych grodzisk z terenu Polski Centralnej pochodzi z pracy J. Sikory (2009). Lista obiektów grodziskowych dla okresu plemiennego obejmuje 12 stanowisk: Barkowice, Chełmo, Czerchów, Ewinów, Łęczyca/Tum, Mnichów, Okopy, Rozprza, Rękoraj, Skoszewy Stare, Szydłów i Witów. Rozpoczynają ją najstarsze Barkowice nad Pilicą, stojące na 
pograniczu prawdziwego grodu i ,zamkniętej” osady (w literaturze tzw. osady quasi-otwarte), poprzez obiekty oceniane morfologicznie jako typowe, do nielicznych założeń wieloczłonowych (Chełmo i Czerchów). Obiektywizacja okresów powstania i funkcjonowania tych warowni nie wygląda najlepiej, ale ich rola jako prawdziwych „miejsc centralnych” (Moździoch 1999; Dulinicz 2000; Kurnatowska 2000), o realnych walorach militarnych lub sensie bardziej sakralnym (jak Chełmo/Góra Chełmowa), od przełomu VIII i IX wieku do połowy X stulecia generalnie nie budzi wątpliwości. Nowe badania w Łęczycy uściśliły datowanie najstarszej fazy grodu tumskiego na szeroko pojęty przełom VIII i IX wieku (Grygiel, Stasiak, Trojan 2014, s. 65-76). Badacze ci sugerują, że pomiędzy powstaniem a przebudową związaną z inicjatywą pierwszych Piastów z końca X wieku, czyli w I fazie użytkowania obiektu, nie pełnił on „funkcji rezydencjonalnej czy mieszkalnej, zarówno w odniesieniu do ówczesnych elit plemiennych, jak i przeciętnej (sic! - podkr. L. K.) ludności” (Stasiak, Trojan 2014, s. 75), ale był refugium i miejscem o cechach kultowych. Myślę, że mniej dyskusyjne jest kolejne zdanie, że ,materiały archeologiczne niestety nie pozwalają na jednoznaczne rozstrzygnięcie kwestii przeznaczenia łęczyckiego grodu" i z taką optyką należy się zgodzić.

Natomiast dla okresu państwowego - od połowy X do połowy XIII wieku - J. Sikora sporządził listę 11 grodzisk: Chełmo, Ewinów, Krzepocinek, Łęczyca/ Tum, Okopy, Rozprza, Rękoraj, Sieradz, Skoszewy Stare, Spicymierz i Szydłów (Sikora 2009, s. 79). Przyjmując tą górną datę pamiętamy, że stopniowe obumieranie drewniano-ziemnych warowni trwało w niektórych przypadkach znacznie dłużej, bo nawet do połowy XIV wieku. Powstanie większości grodów wypada łączyć z czasami ekspansji „polańskiej” na wschód w wieku X, a powstałe blisko połowy tego stulecia Ewinów, Krzepocinek i Szydłów nie przeżyły chyba rozpadu Pierwszej Monarchii w latach 30. XI wieku. Z połową lub 2. połową XI stulecia i odrodzeniem monarchii być może wiązało się powstanie grodów w Sieradzu i Spicymierzu, a słabo określona, ale chyba ograniczona do XII-XIII wieku, jest chronologia II fazy(?) grodu w Okopach. Natomiast o kontynuacji funkcjonowania grodu od czasów plemiennych do państwowych (niekiedy tylko początku tych ostatnich) możemy mówić, pomijając szerzej wspomniany wyżej problem Łęczycy, w przypadkach: Chełma, Ewinowa(?), Rękoraja, Rozprzy, Słoszew Starych i Szydłowa. Przedstawiona tu właściwa dla archeologów optyka nie wyczerpuje jednak całości zagadnienia wczesnośredniowiecznych warowni, gdyż nie znamy reliktów kilku obiektów grodowych notowanych w przekazach pisanych, do tego podstawy chronologii kilku badanych wykopaliskowo są wątke. Dodatkowo nie wszystkie starsze interpretacje formalne i funkcjonalne nadają się dziś do przyjęcia. Przykład wielu kłopotów chronologicznych i interpretacyjnych, które z całą jaskrawością obnażyły najnowsze hipotezy poczynione w wyniku analizy wyników nowych prac terenowych w Łęczycy/Tumie nie wymagają chyba komentarzy. Obraz grodów 
wczesnośredniowiecznych Polski Centralnej wypracowany przez J. Sikorę jest jednak na tyle spójny i pełny, że może stanowić dobry materiał dla pomieszczonych w dalszej części tego tekstu porównań.

Z przedstawionej listy specyfiką lokalizacji wyróżniają się obiekty w Chełmie i Łęczycy/Tumie. Pierwszy jest typowo wyżynny, ulokowany na szczycie najwyższego wzniesienia regionu, czyli Góry Chełmowej. Zaliczyć ją wypada do charakterystycznej raczej dla terenów wyżynnych grupy tzw. świętych gór (Deptuła 1999; Sacrum pogańskie 2010), z otaczającymi szczyt ciągami wałów. O obiekcie tym pisał ostatnio J. Sikora (2010, s. 253-265), podkreślając niepewność dotychczasowej wiedzy o tym bardzo skomplikowanym przestrzennie i słabo jeszcze poznanym obiekcie. Nie do końca jasna jest też sprawa relacji pomiędzy jego sferami sacrum i profanum.

Drugą hipotetyczną ,świętą górą" na interesującym nas terenie jest Góra Świętej Małgorzaty koło Łęczycy, której relacja z grodem i całym tumskim skupiskiem osadniczym także nie jest jeszcze do końca jasna (Marciniak-Kajzer, Lechowicz 2014). Wspomnieć jednak warto, że jest to obiekt znajdujący się około $5 \mathrm{~km}$ od grodziska w Tumie, około $6 \mathrm{~km}$ od grodziska w Czerchowie, w rejonie licznych wczesnośredniowiecznych osad i dwóch cmentarzysk z militariami (Karsznice i Witonia), a więc z wyposażeniem traktowanym dziś jako „elitarne”. Znając dobrze jego sytuację terenową zdecydowanie odrzucić jednak wypada ostatnio publikowane sądy Tomasza Jurka (2014, s. 50-63) wynikające, moim zdaniem, przede wszystkim z nieznajomości tej sytuacji i zarazem niemożności poddania jej pełniejszej analizie przy pomocy warsztatu dostępnego historykowi-mediewiście. Kaplicy (capellam) sancte Marie aput Lanciciam in monte sitam $\mathrm{z}$ falsyfikatu Mieszka III, wystawionego rzekomo w Gnieźnie 28 kwietnia 1145 roku, nie należy bowiem łączyć z jakąś kaplicą w samej Łęczycy. Mało przekonująco brzmi to przede wszystkim połączenie starej obserwacji o podniesieniu o około $1 \mathrm{~m}$ terenu koło kolegiaty (dziś już możemy opowiadać się tak za podniesieniem terenu przed jej budową, jak i zgromadzeniu warstwy wynikłej z samych działań muratorskich), które to działanie mogło na obserwatorach „,robić wrażenie „góry” (Jurek 2014, s. 53). Nie można natomiast polemizować z sądem, że samo pojęcie góry „mogło zaś mieć także bardziej symboliczne znaczenie" (Jurek 2014, s. 53), bo granice dosłownego traktowania jakiejś formy terenowej jako góry nie są przecież określone.

Klasyczny już artykuł Stanisława Zajączkowskiego (1976, s. 83-125) o przejściach przez Błota Łęczyckie znakomicie scharakteryzował środowiskowe determinacje Łęczycy, leżącej na przecięciu „krzyżaka” najważniejszych szlaków komunikacyjnych z ziem polskich. Trudno się więc specjalnie dziwić, że jej geograficznie unikatowe położenie przełożyło się na centralność grodu i całego tumskiego zespołu osadniczego z wczesnego średniowiecza dla Państwa Piastów. Trudniej byłoby wykazać tą centralność w kontekście stołeczności dla danej prowincji czy wręcz kraju, łatwiej w rozumieniu tego skupiska osadniczego jako 
swoistego axis mundi dla całego piastowskiego państwa. Sądzę, że dobrą ilustracją tego uwarunkowania są trzy sukcesywnie po sobie rozwijające się Łęczyce: wczesnośredniowieczna Łęczyca tumska, tzw. Stare Miasto, czyli pierwsza lokacyjna z XIII wieku i późnośredniowieczna - kazimierzowska - obecna, obserwowane w kontekście sinusoidy wzrostów i upadków prowadzących w rezultacie do pełnej lokalności czasów współczesnych. Sądy S. Zajączkowskiego z 1976 roku o szczególności lokalizacji łęczyckiej aglomeracji osadniczej są ogólnie przyjęte w literaturze, a powtarzają je obecnie także autorzy badań terenowych $\mathrm{z}$ lat 2009-2011.

Oba wspominane tu grody - Chełmo i Łęczyca/Tum - stanowią, moim zdaniem, jakości zdecydowanie odmienne od pozostałych, opisywanych tu obiektów, charakteryzujących się z reguły standardowym (nizinnym i około/blisko wodnym, a znajdującym się w sieci lokalnych szlaków) położeniem. Także funkcjonalnie nie są one specjalnie zróżnicowane, gdyż pomijając te, które wcześnie zanikły i te, o których po prostu za mało wiemy, pozostałe wytyczają sieć kasztelańskiej administracji państwa piastowskiego. Warto jednak przypomnieć, że z listy ośrodków kasztelańskich Polski Centralnej, odnotowanej w bulli z datą 1136 rok, liczącej bez centrów zapilickich (Małogoszczy, Skrzyńska/Skrzynna i Żarnowa) pięć obiektów (Łęczyca/Tum, Rozprza, Sieradz, Spicymierz oraz Wolbórz i Ruda), nie jesteśmy w stanie zidentyfikować $\mathrm{w}$ terenie pozostałości dwóch ostatnich warowni. Po nowej publikacji wyników badań archeologicznych zespołu tumskiego (Grygiel, Jurek 2014) wypada poczekać na głosy recenzentów. Ostatnie prace w Rozprzy wydają się całkowicie zmieniać obraz chronologii, przekształceń formalnych i funkcjonalnych tego obiektu, sugerowany dawniej przez A. Chmielowską. Materiały grodowe z Sieradza wymagają przede wszystkim opracowania i ewentualnej publikacji. Natomiast grodzisko w Spicymierzu czeka na to samo, ale też po prostu na nowe badania terenowe.

Ostatnim zbiorem zagadnień, które wypada poruszyć w tym tekście przy okazji charakteryzowania wczesnośredniowiecznych grodów Polski Centralnej, jest problematyka ewentualnej kontynuacji lub dyskontynuacji pomiędzy czasami plemiennymi a państwowymi. Z obiektów powstałych jeszcze w czasach plemiennych z relacjami do kręgu wielkomorawskiego, wcześnie, bo w XI wieku zanikł Czerchów (Trojan 2014, s. 653-668), a aż do późnego średniowiecza funkcjonowała kolejno zmieniająca się: jako kasztelańska i w końcu prywatna Rozprza. Gród ten wraz z czterema pozostałymi siedzibami kasztelańskimi funkcjonował do późnego średniowiecza, co będę omawiał w kolejnym rozdziale tego tekstu. O pewnej kontynuacji i dłuższym funkcjonowaniu we wczesnym średniowieczu mówić możemy, oprócz wspomnianego już Tumu, także w przypadku Skoszew Starych (por. niżej). Warto też zwrócić uwagę, że z dwóch grodów, które stały się także stolicami ziem (łęczyckiej i sieradzkiej), w tym ostatnim przypadku obiekt grodowy nie miał starszej metryki, gdyż powstał dopiero w rezultacie działań 
struktur państwowych po odrodzeniu się monarchii w połowie lub 2. połowie XI wieku. Bardzo też prawdopodobne, że dopiero wtedy rozpoczął swe prawdziwe funkcjonowanie cały system kasztelański Polski Centralnej.

Opisana sytuacja wskazuje, że funkcjonowanie wczesnośredniowiecznych grodów drewniano-ziemnych na interesującym nas terenie podzielone było kilkoma cezurami chronologicznymi. Pierwszą, rozciągniętą w czasie i jeszcze słabo określoną datami bezwzględnymi, było powstawanie grodów plemiennych, drugą wznoszenie $\mathrm{z}$ inicjatywy Piastów, przed i około połowy $\mathrm{X}$ wieku grodów państwowych. Akcja ta łączyła się z destrukcją i w jej efekcie zanikiem kilku obiektów plemiennych. Następnie upadek państwa w latach 30. XI wieku spowodował bezpowrotne zniszczenie co najmniej trzech obiektów (Ewinów, Krzepocinek, Szydłów). Łęczyca/Tum i Rozprza trwały do końca wczesnego średniowiecza, zaś Sieradz i Spicymierz powstały dopiero w efekcie odbudowy państwa w połowie XI wieku, istniejąc wraz z dwoma wymienionymi wcześniej aż do schyłku funkcjonowania systemu kasztelańskiego i generalnej zmiany ustroju państwowego.

Uwarunkowania terenowe, jako jedna z determinant przemian osadniczych, mogą być dosłownie traktowane tylko w przypadku Łęczycy/Tumu. W pozostałych są one widoczne znacznie mniej wyraźnie lub niewidoczne prawie wcale. Ważniejszą chyba rolę przypisać wypada osadniczemu nasyceniu pewnych regionów i dynamice przemian osadniczych. Z procesami tymi łączyłbym na przykład ,zastąpienie” Ewinowa przez nowy gród w sąsiednim Spicymierzu, ale już nie relację Witów-Sieradz, bliskie terytorialnie i połączone tą samą rzeką, ale rozdzielne czasem funkcjonowania obu warowni. Innej jeszcze relacji domyślać się możemy w zaniku Rękoraja (jeszcze w XI czy już na początku XII wieku?), znajdującego się zbyt blisko kasztelańskiej i dobrze się wtedy rozwijającej Rozprzy. Nie do końca też wiemy, jak odbyło się przeniesienie dawnej kasztelanii rudzkiej (gdzie w wieku XII wzmiankowano castellum, a w XIII organizm miejski) do sąsiedniego Wielunia, w którym w końcu XIII wieku (lata 1281 i 1283) odnotowano zarówno obecność ośrodka kasztelańskiego, jak i civitas (Rosin 1963, s. $144-146,169-174)$.

W sumie najbardziej czytelnym dorobkiem wczesnego średniowiecza Polski Centralnej, niejako wprowadzającym region w następną epokę, były grody kasztelańskie z wyróżniającą się wśród nich prawdziwie centralną Łęczycą/Tumem. Niepokoi natomiast wyraźny rozdźwięk w interpretacji późniejszych losów tego grodu, gdyż w świetle źródeł pisanych był obiektem kasztelańskim już w 2. ćwierci XII wieku, zaś według nowych sądów archeologów, opartych na analizie źródeł materialnych zgromadzonych w latach 2009-2011 stał się nim dopiero w latach 50. XIII wieku. 
Nie będę tu powracać do wielokrotnie opisywanej przełomowości zdarzeń i procesów mających miejsce w wieku XIII, gdyż mają one dużą i interesującą literaturę. Niedawno zresztą o relatywizmie przemian tego stulecia na terenie różnych terenów Polski pisałem (Kajzer 2014, s. 7-26), sugerując, że na interesującym nas obszarze gros z nich dokonało się pomiędzy połową wieku XIII a zniszczeniem i odbudową regionu po najeździe krzyżackim we wrześniu 1331 roku. Cezura ta niejako zamknęła okres przemian i umożliwiła formowanie się nowych jakości społecznych i gospodarczych, a w dalszej kolejności także politycznych, typowych dla okresu późnego średniowiecza. Jak wiemy, do najważniejszych zjawisk obserwowanych w wieku XIII zalicza się procesy lokacyjne, zwane niekiedy rewolucją miejską. Na interesującym nas terenie nie miały one, tak jak na przykład na Pomorzu Zachodnim, charakteru przemian rewolucyjnych (Rębkowski 2001). Problematyka ta, związana z procesami rozwoju łęczyckiego ośrodka osadniczego, obserwowanego od czasów plemiennych do późnego średniowiecza, będzie jeszcze poruszana w tym tekście.

Po tytułowych grodach, wypada się teraz zatrzymać nad zamkami. Podobnie jak w przypadku prac J. Sikory, dotyczących wczesnego średniowiecza, tu pragnę skorzystać z własnych studiów nad późnośredniowiecznymi i wczesnonowożytnymi założeniami obronnymi i obronno-rezydencjonalnymi z terenu Polski (Kajzer 2004). Słowo „zamki” rozumiem bowiem szeroko i w jego obrębie chciałbym uwzględnić tak ,prawdziwe zamki”, jak i mniejsze warownie, z których większość wzniesiona została z drewna i wywodziła się z paneuropejskiej tradycji obronnej siedziby feudalnej typu motte. Archeolodzy ich relikty określają najczęściej mianem tzw. gródków stożkowatych, w źródłach pisanych występują z reguły jako fortalicje, czy wieże albo dwory lokowane na kopcach ziemnych.

Rozpocznę jednak od zamków, czyli największych (jeśli chodzi o rozmiary) i najważniejszych warowni Polski Centralnej. Zostały one już elementarnie poznane, nadal jednak pozostaje sporo wątpliwości, nawet dotyczących sporządzenia pełnej listy takich warowni. Biorą się one z kilku przyczyn, z których jako najważniejszą traktowałbym brak możliwości porównania pojawiającego się w źródłach pisanych słowa castrum z odpowiednim (ziemnym lub budowlanym) reliktem lub z odpowiednią, z reguły najstarszą fazą użytkowania danej warowni. Niekiedy średniowieczni skrybowie stosowali też określenie castrum niejako na wyrost, posługując się nim przy opisie warowni, których skala budowlana i walory obronne kompletnie na to, przynajmniej zdaniem współczesnych uczonych, nie pozwalały. Zastrzeżenie to jest chyba niezbędne, gdyż nazewnictwo ze źródeł bywa często dość labilne - podporządkowane raczej leksykalnym przyzwyczajeniom piszących niż realiom budowlanym, a dalekie od ortodoksji uczonych zajmujących się obecnie zamkami czyli kastellologów. 
Zamki z terenu Łęczyckiego, to oprócz warowni w kazimierzowskiej Łęczycy, także Besiekiery, Borysławice Zamkowe, Brzeziny, Inowłódz, Oporów, Sobota i Ujazd. Cztery z nich obserwować możemy i zarazem badać w stanie kubaturowym, Oporów funkcjonuje jako wnętrze użytkowe do dziś, już nieistniejący Ujazd poznany został dzięki badaniom archeologiczno-architektonicznym, zaś w przypadku dwóch pozostałych wiemy bardzo mało. W przypadku Brzezin znamy tylko źródłowe określenie castrum, nie jest natomiast znana jego forma architektoniczna, zaś w Sobocie wiemy tylko o obecności w nowszej bryle pozostałości zamkowej heksagonalnej wieży.

Dłuższa jest lista zamków Sieradzkiego z ziemią wieluńską. $Z$ tej ostatniej należy wymienić zachowaną w stanie trwałej ruiny warownię w Bolesławcu nad Prosną i już nieistniejącą w Wieluniu. Natomiast zamki historycznego województwa sieradzkiego, w skład którego wchodziły cztery powiaty (piotrkowski, radomszczański, sieradzki i szadkowski) to: Bąkowa Góra, Brzeźnica, Byki, Lutomiersk, Majkowice, Sieradz, Uniejów i Wolbórz. Do wykazu tego zalicza się też często zamek w Piotrkowie Trybunalskim, którego obecność w późnym średniowieczu jest jednak wątpliwa, a współczesny wieżowy wygląd ogólnie znany, ponadto miniaturowe, ale prezentujące wszystkie cechy prawdziwego zamku (czyli obwód murowany, dom i wieżę) Wojsławice, a także już nowożytne, ale nigdy do końca nie zrealizowane (może na skutek klęski szwedzkiego „potopu”?) założenie typu palazzo in fortezza w Gorzkowicach koło Piotrkowa Trybunalskiego. Jako prawdziwy zamek trudno też traktować podpiotrkowskie Byki, mające w obecnej kreacji charakter nowożytnej rezydencji. Jeszcze trudniejszy jest problem zamku w Brzeźnicy, gdyż nie znamy nie tylko jego reliktów, ale nawet dokładniejszej lokalizacji. Z wymienionej podstawowej listy w stanie użytkowym zachowany jest tylko Uniejów, w stanie trwałej ruiny Bąkowa Góra, pozostałości Lutomierska znajdują się w obrębie obecnego klasztoru Salezjanów, zaś nieistniejące zamki w Majkowicach, Sieradzu i Wolborzu znamy z mniej lub bardziej rozsądnych badań terenowych.

Przedstawione wyżej zestawienie należy uporządkować własnościowo. I tak, z mecenatem państwowym czyli królewskim wiąże się obiekty w Bolesławcu, Brzeźnicy, Inowłodzu, Łęczycy, Piotrkowie Trybunalskim, Sieradzu i Wieluniu. Mniej zamków powstało z inicjatywy dostojników Kościoła (Borysławice Zamkowe, Oporów, Uniejów i Wolbórz), przy czym zaznaczyć wypada, że pierwsze dwa są na granicy zamków kościelnych i prywatnych, gdyż wzniesiono je z inicjatywy książąt Kościoła, ale w centrach ich rodzinnych kluczy majątkowych (Wojciecha Jastrzębca i Oporowskich). Typowe zamki kościelne to zatem tylko Uniejów, należący do arcybiskupów gnieźnieńskich i Wolbórz biskupów włocławskich. Pozostałe warownie powstały z inicjatywy osób prywatnych, jednak nie rycerstwa, jak się często pisze nawet $\mathrm{w}$ profesjonalnej literaturze, ale zajmującej wysokie 
urzędy państwowe elity możnowładczej. Tylko ich bowiem, w polskich warunkach i możliwościach, stać było na wzniesienie potężnego, obronnego rodowego gniazda.

Już sama lokalizacja późnośredniowiecznych zamków państwowych zachęca do porównań z opisaną wyżej sytuacją terenową grodów z wczesnego średniowiecza. Zamki w Łęczycy, Sieradzu i Wieluniu wyznaczają sieć lokalnych centrów administracyjnych odrodzonej monarchii. W przypadku dwóch pierwszych miejscowości powielają lokalizację starszych ośrodków kasztelańskich, w Wieluńskiem mamy do czynienia z przesunięciem terenowym o niespełna $4 \mathrm{~km}$. Nie jest to zresztą przypadkiem, gdyż większość fundacji zamkowych Kazimierza Wielkiego i innych władców wyznacza, po prostu siatkę państwowych stolic - ośrodków wojewódzkich i powiatowych. Tradycja ciągłości od grodu do zamku rysuje się jednak w każdym z przypadków inaczej. W Sieradzu murowany zamek Kazimierz Wielki zaczął po prostu budować na starym grodzie, ulokowanym w dolinie, w zabagnionych łąkach nad Wartą. Inaczej postąpił ten władca w Łęczycy, gdzie ceglana warownia znalazła się w obrębie murów obwodowych lokacyjnego miasta. Na Wieluńszczyźnie nastąpiła natomiast, jak wspomniano, translokacja samego centrum, z wszystkimi wynikającymi z tego konsekwencjami.

Oprócz różnic lokalizacyjnych i odmienności poszczególnych, następujących po sobie sekwencji kolejno wznoszonych warowni, wymienione wyżej zamki królewskie bardzo różnią się między sobą formalnie. Dobrze ilustruje to z jednej strony na przykład Bolesławiec, w założeniu murów obwodowych zbliżony do owalu, ulokowany poza miastem, na wyniosłym wzniesieniu nad Prosną, a do tego być może kryjący w sobie relikty XIII-wiecznego castrum. Z drugiej strony jest to zbudowany na surowym korzeniu czworoboczny Inowłódz, leżący też poza miastem, w terenie nizinnym, podobny do innych, bardzo licznych i jednocześnie zróżnicowanych realizacji „zamków kazimierzowskich”, stanowiących mniej lub bardziej dosłowne nawiązanie do schematów centralnoeuropejskich zamków kasztelowych. W sumie opisane wyżej zamki prezentują większość typów formalnych późnośredniowiecznych warowni, dzieląc się wyraźnie na obiekty ceglane na północy i kamienne na południu, choć i tego podziału nie można traktować zbyt dosłownie. Równie zróżnicowane są też zamki prywatne, do których charakterystyki powrócę przy opisywaniu grupy mniejszych warowni.

Tak więc, omijając obie stolice regionalne, lokalizacja wczesnośredniowiecznych grodów i późnośredniowiecznych zamków państwowych w zasadzie rozmija się, a o wędrówce lokalnych centrów pomiędzy czasami wczesnego i późnego średniowiecza dobrze informuje translokacja z Rudy do Wielunia. Owo „mijanie się" jest zdecydowanie słabiej widoczne w innych grupach warowni, szczególnie obiektów prywatnych.

Jeśli wspomniane wyżej zamki prywatne, wzniesione z kamienia lub cegły, wytyczają sieć posiadłości i zarazem fundacji najwęziej pojętej, najbogatszej i najmożniejszej elity feudalnej, to szerzej zarysowana elita urzędnicza, której 
znaczenie budowały wielowioskowe klucze majątkowe (najlepiej z centrum ulokowanym w małym miasteczku, czyli tzw. kluczy miejskich - por. Zajączkowski 1966), mieszkała w późnym średniowieczu w drewnianych ścianach, czyli w wieżach i dworach lokowanych na kopcach ziemnych, otoczonych fosami i sprzężonych z zapleczem gospodarczym. Tzw. gródki stożkowate nie były bowiem początkowo, jak się dawniej uważało, „siedzibami średniego rycerstwa”, ale bogatych i potężnych przedstawicieli tego stanu, który to odłam można też określić jako możnowładczy (Kajzer 1987, s. 105-126). Wypada tu jednak zaznaczyć, że w miarę przekształceń wieków średnich budowy takich siedzib podejmowali się coraz mniej znaczący fundatorzy. Liczba tych warownych zespołów dworów, czy używając określenia typowego dla historyków architektury późnośredniowiecznych „dworów obronnych”, jest trudna do określenia, gdyż z oczywistych przyczyn żaden z nich nie dotrwał do naszych czasów. Pozostałościami są jeszcze niekiedy zachowane w krajobrazie kopce/nasypy ziemne, a wiedza o nich pochodzi w znacznej mierze z badań archeologicznych i nielicznych wzmianek pisanych. Pierwsze zestawienie, liczące około 40 obiektów tego typu (ale bez stożkowatych gródków z Wieluńskiego), sporządziła jeszcze w latach 50. XX wieku J. Kamińska (1953). W ponad pół wieku potem autor tego tekstu zidentyfikował ich ponad 200 (Kajzer 2004). Przy czym liczba ta obejmuje identyfikowane w terenie nasypy ziemne (lub historyczne o nich wzmianki), dosłowne sformułowania zawarte w źródłach pisach (fortalicium, fortalicium sive propugnaculum, mons seu fortalicium, curia cum/et fortalicio, fortalicium seu turris, turris, ale też np. curia ibidem videlicet alba stuba et caminata in monticulo ${ }^{1}$ ) lub tylko niepewne poszlaki wynikające tak ze znajomości, terenu jak i niejednoznacznych przekazów źródłowych ${ }^{2}$.

Już tylko samo zestawienie nazw miejscowości, w których zidentyfikowano relikty takich warowni (lub informacje źródłowe o ich istnieniu) oraz dużych, prawdziwych zamków z listą grodów wczesnośredniowiecznych, pozornie nie wskazuje na bliskie relacje obu tych grup, choć od obserwacji tej zdarzają się wyjątki. I tak, na przykład najpierw plemienny, a potem wczesnopaństwowy, wczesnośredniowieczny gród w Skoszewach Starych przeżył niejako drugą młodość w późnym średniowieczu, gdy w obrębie starych wałów ulokowano warowny zespół dworski, funkcjonujący co najmniej do lat szwedzkiego potopu. Sama zaś wieś (potem miasteczko) stała się ośrodkiem wielowioskowego klucza majątkowego Strykowskich, Warszyckich, Duninów i Skoszewskich. Rozprza jest natomiast przykładem obiektu sięgającego początkami wieku IX, a u schyłku

\footnotetext{
1 Jak na przykład w Ładzicach koło Radomska (Nowak, Szymczak 1993, s. 89).

${ }^{2}$ Liczba tych zidentyfikowanych dworów obronnych/gródków stożkowatych będzie zapewne przyrastać (np. nieuwzględnione w zestawieniu z 2004 roku Wodzierady). Por. też na przykład odkrycie w Giecznie koło Łodzi, gdzie dopiero w 2015 roku zidentyfikowano i wstępnie przebadano obiekt pochodzący z fundacji możnych w późnym średniowieczu - Toporów. Dziękuję serdecznie panu dr. J. Sikorze za tę informację.
} 
funkcjonowania - gdzieś na przełomie XIII i XIV stulecia - została przekształcona w obiekt „stożkowaty”, należący do przedstawicieli rodu Nagodziców. Także długą tradycję ma Chełmo: od sanktuarium pogańskiego(?) przez wczesnośredniowieczny gród, do centrum dużej feudalnej włości prywatnej, której ostatnim śladem jest murowany pałac, kryjący w sobie mury co najmniej XVII-wieczne.

O jeszcze ciekawszej sekwencji mówić możemy w szerokiej dolinie nadwarciańskich łąk, czyli w Ewinowie nad Wartą. Krótko użytkowany (pomiędzy połową X a połową XI wieku) gród upadł, co prawda definitywnie, ale obok niego - w Spicymierzu - powstała inna warownia, pełniąca w monarchii piastowskiej funkcje kasztelańskie. Niestety, nie znamy dokładniejszej daty tej ,zamiany”. Natomiast ostateczny kres Spicymierza przyniósł być może dopiero najazd krzyżacki z 1331 roku, lecz wtedy to stare centrum zostało z kolei zastąpione przez arcybiskupi zamek w Uniejowie, stanowiący ośrodek dużego klucza majątkowego.

Elementy kontynuacji pomiędzy wczesnym a późnym średniowieczem są więc nieczęste i w wyjątkowych przypadkach czytelne. Rolę cezury zrywającej tu pewną ciągłość w skali makro przypisać należy całemu blokowi przekształceń określanych najczęściej jako ,przemiany wieku XIII”, a zakończonych zniszczeniami starych struktur przez Krzyżaków w 1331 roku. Równocześnie jednak trzeba pamiętać o znanym dokumencie Kazimierza Wielkiego z 1357 roku dla dóbr arcybiskupstwa gnieźnieńskiego, w którym król przypominał, że zwolnienie arcybiskupich poddanych od obowiązku budowy grodów nie dotyczy „starych grodów" w Gnieźnie, Łęczycy, Nakle i Sieradzu. Przemiany łączone powszechnie z wiekiem XIII i początkiem następnego stulecia sprawiły jednak, że zwolnienie to nie odmieniło w sposób zasadniczy losów starej warowni łęczyckiej.

Późne średniowiecze na interesującym nas terenie było więc czasem murowanych zamków i drewnianych dworów obronnych - fortalicji. Te ostatnie, stanowiące bezpieczne siedziby elity rycerskiej, z reguły pełniącej funkcje urzędnicze, wyznaczone były siecią wielowioskowych kluczy majątkowych, których terytorialny i funkcjonalny związek z warowniami z wcześniejszych okresów jest prawie nieczytelny.

\section{IV}

Posiadanie we wczesnośredniowiecznej Europie klasztoru było prawdziwym skarbem. Jednak na fundację taką, wymagającą zaangażowania wielkich środków i znacznej determinacji, stać było tylko rody cesarskie, najwyższych dostojników Rzeszy i generalnie bardzo wąsko pojętą elitę ówczesnej „starszej” Europy. Jeśli tak wyglądały realia postrzymskiej i pokarolińskiej części naszego kontynentu, to nie może dziwić znikoma liczba klasztorów w państwie Pierwszych Piastów. Optymizm badawczy Gerarda Labudy, który jeszcze niedawno z czasami 
Bolesława Chrobrego łączył aż cztery domy, został sprowadzony do realiów przez młodszych badaczy (Urbańczyk 2008; 2012; Sikorski 2011; 2012a; 2012b), zaś jedynym z tego okresu był zapewne efemeryczny dom w Międzyrzeczu. Przyjąć więc wypada, że klasztory na ziemiach polskich powstawały dopiero w okresie drugiej monarchii, czyli od połowy XI wieku i z czasami tymi należy łączyć dwa znane domy benedyktyńskie - Mogilno i Tyniec, budzące liczne wątpliwości interpretacyjne, najbardziej nas tu interesujące opactwo Sanctae Mariae in castello Lancicie, a także Lubiń i jeszcze kilka(?) innych. Łącznie w XI i XII wieku na ziemiach polskich powstało, zapewne w dwóch horyzontach chronologicznych, osiem domów benedyktyńskich (Kłoczowski 2010). W pierwszym, XI-wiecznym, były one fundacjami władców, w drugim, z 1. połowy XII wieku do głosu doszli już najwybitniejsi możnowładcy - Piotr Włostowic, Wojsław, Sieciech Młodszy, Awdańcy, Jaksa z Miechowa itp.

Wiek XII był jednak czasem cystersów i różnych odmian reguły kanoników regularnych. Z 20 domów tych zakonników powstałych wtedy na ziemiach polskich dwa ufundowano na interesującym nas terenie: cystersów w Sulejowie nad Pilicą (1177 rok) i norbertanów w Witowie (1185? rok) koło Piotrkowa Trybunalskiego (a więc też obok Sulejowa). Dominacja klasztorów mniszych i kanoniczych ostatecznie zanikła w XIII wieku dzięki Franciszkowi z Asyżu i Dominikowi Guzmanowi, którzy obserwując przemiany swej współczesności docenili potrzebę nowej dewocji dla nowego społeczeństwa i stworzyli żebracze reguły zakonne. Fundowane przez dominikanów i franciszkanów domy przeanalizuję poniżej.

Tak więc we wczesnym średniowieczu na terenie Polski Centralnej powstały tylko trzy centra monastyczne: tajemnicze opactwo łęczyckie oraz domy - cystersów w Sulejowie i norbertanów w Witowie. Olbrzymia literatura dotycząca opactwa łęczyckiego zwalnia mnie z konieczności zaprezentowania go, ograniczę się tu do stwierdzenia, że lokalizacja tej monarszej fundacji jest zarówno dowodem, jak i efektem prawdziwie centralnego położenia łęczyckiej aglomeracji osadniczej we wczesnośredniowiecznej Polsce. Natomiast jej zanik (chyba w latach 30. XII wieku) jednym ze świadectw zmian relacji pomiędzy reprezentowanym przez arcybiskupa gnieźnieńskiego Kościołem a państwem. Z inicjatywą benedyktynów z wielkopolskiego Lubinia związane jest też założenie prepozytury w Jeżowie na samej granicy Łęczyckiego i Mazowsza, ale już na terenie tej drugiej prowincji. Powstanie jej odnieść można do 3. ćwierci XII wieku, zaś w 1180 roku, w obecności legata Rajnalda odbyto tam synod. Problem tej słabo poznanej prepozytury wymaga dalszych badań, także terenowych, ale z racji „mazowieckości” domu sprawy tej nie będę tu rozwijać.

Nieco inaczej interpretować można okoliczności erygowania opactwa w Sulejowie, powstałego na małopolskim brzegu Pilicy, vis a vis miasta w ziemi sieradzkiej. Sprowadzony w Morimondu konwent osadzony został w obrębie starszego centrum osadniczego, ulokowanego przy przeprawie przez Pilicę (Augustyniak 
2005). Opactwo erygowano więc na starym szlaku (notowanym w 1237 roku jako via antiqua), wiodącym z Żarnowa do Sulejowa, dalej z Rusi na północ i zachód, na cyplu odciętej parowami wysoczyzny, wcinającej się w rzeczną dolinę (Augustyniak 2014, s. 135-166). Było ono inicjatywą Kazimierza Sprawiedliwego; także współpracujących z nim biskupów krakowskich - Gedki i Pełki, wspomożoną donacjami możnych, ale w gruncie rzeczy fundację tę i jej lokalizację traktować można przede wszystkim jako świadectwo szerzej zakrojonych politycznych ambicji księcia (Dobesz 1995). Konwent szarych mnichów osadzono bowiem na jednym z najważniejszych wtedy szlaków komunikacyjnych o wielkim znaczeniu handlowym, ale też politycznym, gdyż stanowił najkrótszą drogę z Krakowa do Gniezna i centrum Wielkopolski. Opactwo sulejowskie można więc traktować jako efekt globalnej polityki Kazimierza Sprawiedliwego, budującego sobie swoiste przyczółki, zmierzające do objęcia władaniem obu głównych prowincji państwa, co mogło stanowić drogę prowadzącą w stronę ewentualnej królewskiej koronacji.

Witów - leżący o pół dnia wolnego spaceru od Sulejowa - powstał na starej drodze z Sulejowa do Piotrkowa Trybunalskiego, początkowo prawdopodobnie jako opactwo dwukonwentowe. Stanowiło ono fundację możnego Wita z rodu Janinów (chyba nie identycznego z biskupem płockim Witem z Chotla, †około 1206 roku), którego przedstawiciele przyczynili się do powstania dwóch lub trzech domów norbertańskich (także świętokrzyskie Busko i Płock). Mimo licznych publikacji (np. Rajman 1996) jest to obiekt nieposiadający przekonującej monografii, a poznanie średniowiecznego opactwa i jego ówczesnej roli utrudnia także rozebranie jeszcze romańskiej(?) lub już gotyckiej substancji zabytkowej, zastąpionej XVIII-wiecznym barokiem. Zbyt mało wiemy też o ewentualnych majątkach należących do przedstawicieli rodu Janinów w tym rejonie ziem polskich. Jak dotąd, nie spotkałem też przekonującego wytłumaczenia przyczyn, dlaczego dwa bogate opactwa powstały tak blisko siebie, na prawie tym samym szlaku drożnym i do tego w podobnym czasie, co przecież nie raz owocowało konfliktami między nimi. Może stanowiło to dowód pewnej korekty politycznych planów, które doprowadziły do powstania Sulejowa?

Powstające w XIII wieku klasztory zakonów żebraczych, czyli dominikanów i franciszkanów, wyznaczały już nową epokę, także zresztą architektoniczną, gdyż ich świątynie prezentowały już cechy nowej, gotyckiej stylistyki. Najwcześniejszym klasztorem Dominikanów w Polsce Centralnej był dom w Sieradzu, fundowany jeszcze przez Konrada Mazowieckiego, a potem wzmocniony działaniami jego syna Kazimierza (Grzybkowski 1975). Pochodzący już z 2. połowy XIII wieku dom powstał także na Starym Mieście w Łęczycy, skąd w efekcie translokacji osiedla w inny rejon, znalazł się w obrębie murów tzw. miasta kazimierzowskiego. Nieco później ufundowano jedyny na interesującym nas terenie klasztor franciszkański - w Brzeźnicy/Radomsku. 
Reasumując, klasztory mnisze i kanonickie Polski Centralnej we wczesnym średniowieczu stanowiły wyznacznik ówczesnej specyfiki regionalnej i sytuacji osadniczej, wynikającej raczej z procesów bardziej globalnych niż lokalnych. Opactwo łęczyckie, a potem tumska kolegiata, wyznaczały prawdziwe centrum Polski wieku XII. Sulejów i Witów ulokowano na jednym z najważniejszych szlaków komunikacyjnych prowadzących z Krakowa do Gniezna. Choć pierwszy powstał z inicjatywy książęcej, drugi zaś możnowładczej, możliwe, że oba traktować można jako efekt meandrów globalnej polityki Kazimierza Sprawiedliwego. Natomiast domy zakonów żebraczych wyznaczały sieć ważnych późnośredniowiecznych ośrodków miejskich i nie jest przypadkiem, że oba XIII-wieczne klasztory dominikańskie erygowano w lokalnych stolicach regionu.

\section{V}

Pojawiające się na zakończenie poprzedniego akapitu „ośrodki miejskie” zmuszają do wyjścia poza tytułowy zakres tego tekstu i poświęcenia uwagi także i miastom, traktowanym jako czwarty już element opisywanej tu panoramy. Czwarty, a zarazem ostatni, gdyż zamykający ostatecznie sprawy relacji pomiędzy wczesnośredniowiecznymi grodami a późnośredniowiecznymi warowniami, wokół których funkcjonowało osadnictwo wiejskie, a w skali makro - bo nie tylko przecież sakralnej - wielce liczyły się nieliczne klasztory. Właśnie powstające w XIII wieku miasta lokacyjne i fundowanie w najbogatszych, największych z nich klasztorów zakonów żebraczych było wyznacznikiem nowej jakości społeczno-gospodarczej, a zarazem nowej epoki, czyli późnego średniowiecza.

Jak wynika z wcześniejszych badań Ryszarda Rosina (1971) i nowych - Mariusza Kuleszy (2001), na obszarze Polski Centralnej lokowano około 70-80 miast. Ich sieć była więc przynajmniej teoretycznie znacznie gęściejsza niż wcześniejszych i współczesnych warowni - wczesnośredniowiecznych grodów i murowanych zamków, nie mówiąc już o nielicznych klasztorach. W rzeczywistości, posługując się klasyfikacją Henryka Samsonowicza (Bogucka, Samsonowicz 1986, s. 115) tylko 11 z nich (Piotrków, Radomsko, Sieradz, Szadek, Uniejów, Warta, Wieluń w Sieradzkiem oraz Brzeziny, Inowłódz, Łęczyca i Piątek w Łęczyckiem) zaliczyć można do „miast II kategorii”, czyli prawdziwie liczących się, przynajmniej w skali lokalnej, ośrodków miejskich. Należy też zwrócić uwagę, że na opisywanym terenie nie ukształtowało się żadne miasto I kategorii. Ciekawe jest też porównanie wymienionych wyżej największych miast z listą założeń lokowanych już w wieku XIII. Łącznie było ich 19 (od Łubnic i Warty z lat 1253 i 1255 do Sulejowa z 1296 roku), a w obu zestawieniach powtarzają się: Warta, Sieradz, Radomsko, Łęczyca, Wieluń i Szadek, z czego wynika, że ośrodki lokowane najwcześniej stanowiły przeszło połowę najważniejszych i największych miast 
regionu (Bogucka, Samsonowicz 1986, s. 87). W drugim zestawieniu dziwić może brak Piotrkowa, który był lokowany około 1313 roku, ale tu zwraca uwagę wczesna data sąsiedniej Rozprzy (przed 1272 rokiem). Podobnie wcześniej niż Wieluń lokowana była pobliska kasztelańska Ruda (przed 1264 rokiem). W sumie nie ulega wątpliwości, że procesy lokacyjne objęły najwcześniej stare stolice regionalne, zaś w kilku przypadkach mamy do czynienia z tzw. starymi miastami przenoszonymi (też po kolejnej lokacji) na nowe, już obecne miejsca. Najlepszym tego przykładem może być Łęczyca, której dzieje pomiędzy wczesnym a późnym średniowieczem zamknąć można - jak już wspominałem - w triadzie: Łęczyca tumska czyli wczesnośredniowieczna, Stare Miasto, czyli lokacyjna Łęczyca XIII-wieczna i Łęczyca kazimierzowska, czyli późnośredniowieczna i zarazem nam współczesna.

\section{VI}

To krótkie naświetlenie relacji pomiędzy grodami, zamkami, klasztorami i miastami Polski Centralnej od okresu plemiennego do państwa ostatnich Piastów, zachęca do uogólnień, szczególnie w aspekcie obserwowanej kontynuacji i dyskontynuacji chronologicznej, a także relacji pomiędzy poszczególnymi typami struktur osadniczych. Krajobraz kulturowy zdeterminowany najpierw przez plemienne, a potem już piastowskie grody zarysował pewną siatkę miejsc ważnych, z pozostającą poza klasyfikacją, autentycznie centralną Łęczycą tumską. Powtórzyć tu bowiem trzeba tezę o autentycznej wyjątkowości Łęczycy, co wynikało zresztą (a może było raczej powodem?) jej lokalizacji. Wyjątkowość ta, po czterech wiekach egzystencji skurczyła się do roli centrum prowincjonalnego, funkcjonującego w przedziale czasowym XIV-XVIII/XIX wieku, a obecnie zepchnięta została do roli jednego z około 300 ośrodków zupełnie lokalnych.

Wyraźne wahnięcie przyniosło najpierw opanowane terenu Polski Centralnej przez „Polan”, a potem stworzenie sieci ośrodków kasztelańskich, wytyczających regionalne centra polityczne i osadnicze. Funkcjonowanie ich zostało naruszone przez przemiany wieku XIII, a ostatecznie zanikły w XIV stuleciu, gdy na miejscu kilku takich grodów zbudowano także państwowe zamki. Przemiana ta ustaliła generalnie obraz centrów i innych struktur osadniczych regionu, czytelnych aż do końca Rzeczypospolitej Szlacheckiej.

Począwszy od połowy XIII wieku w siatkę ową zaczęły wpisywać się siedziby obronno-mieszkalne o charakterze dworów obronnych, których lokalizację wyznaczał rozkład ośrodków wielkiej własności ziemskiej, bo nie tylko włości rycerskich. Także w wieku XIII rozprzestrzenienie i rolę najważniejszych ośrodków osadniczych oraz targowych niejako powielono lokacjami miejskimi. Powstawały one tak w oparciu o wczesnomiejskie struktury przedlokacyjne, jak 
i miały rodowód wiejski lub wręcz lokowane bywały na surowym korzeniu. Tak pozornie odlegle od siebie kategorie osadnicze - miasto i włość feudalna z obronną siedzibą właściciela - w praktyce nie były jednak tak sobie obce. Ideałem późnośredniowiecznego feudała było bowiem posiadanie kilkuwioskowego, zwartego terytorialnie klucza majątkowego, w którego centrum znajdowała się rezydencja i kościół, a działaniem potencjalnie najbardziej dochodowym mogło być uzyskanie dla takiej wsi praw miejskich. Struktura taka zapewniała bezpieczeństwo, szybszy niż na wsi obrót kapitału, a w końcu zaspakajała tęsknotę do posiadania własnej rodowej nekropolii, którą to rolę we wcześniejszych fazach wieków średnich spełniały właśnie rodowe fundacje klasztorne.

Kończąc żałuję, że w tekście o tych rozmiarach mogłem tylko zarysować, a nie w pełni zreferować tytułową problematykę, do której wypadałoby jeszcze nie raz powrócić.

\section{Literatura}

Augustyniak J.

2005 Cysterskie opactwo w Sulejowie. Rozwój przestrzenny do końca XVI wieku $w$ świetle badań archeologiczno-architektonicznych w latach 1989-2003, Łódź.

2014 Średniowieczne przeprawy przez Pilicę i ich obrona. Żarnowiec-PrzedbórzSulejów-Inowtódz, Łódź.

Bogucka M., Samsonowicz H.

1986 Dzieje miast i mieszczaństwa w Polsce przedrozbiorowej, Wrocław. Chmielowska A.

1979 Badania nad wczesnośredniowiecznym osadnictwem grodowym i jego wiejskim zapleczem na terenie Polski Środkowej, Acta Universitatis Lodziensis. Zeszyty Naukowe Uniwersytetu Łódzkiego, Nauki humanistyczno-społeczne, Folia Archaeologica, seria 1, nr 36, s. 35-51.

Deptuła C.

1999 Święte góry w dawnej Polsce. Impresja z pogranicza średniowiecza i renesansu, [w:] Miejsce rzeczywiste, miejsce wyobrażone, red. M. Kitowska-Łysiak, E. Wolicka, Lublin, s. 215-241.

Dobesz J.

1995 Działalność fundacyjna Kazimierza Sprawiedliwego, Poznań.

Dulinicz M.

2000 Miejsca, które rodza władze (najstarsze grody stowianskie na wschód od Wisty), [w:] Człowiek, sacrum, środowisko. Miejsca kultu we wczesnym średniowieczu, Spotkania Bytomskie 4, red. S. Moździoch, Wrocław, s. 85-98. Grzybkowski A.

1979 Wczesnogotycki kościót i klasztor dominikański w Sieradzu, Warszawa. 
Jurek T.

2014 Pierwsze wieki historii Łęczycy, [w:] Początki Łęczycy, t. 3, s. 7-191.

Kajzer L.

1987 Czy tzw. gródki stożkowate byty siedzibami „średniego rycerstwa”?, [w:] Średniowieczne siedziby rycerskie $w$ ziemi chetmińskiej na tle badań podobnych obiektów na ziemiach polskich, red. A. Kola, Toruń, s. 105-126.

2003 Z badań wczesnego średniowiecza na terenie Polski Centralnej, [w:] Stowianie i ich sasiedzi we wczesnym średniowieczu, red. M. Dulinicz, LublinWarszawa, s. 55-61.

2004 Zamki i dwory obronne w Polsce Centralnej, Warszawa.

2007 Polska Centralna $w$ XIII wieku - wstępna próba charakterystyki archeologicznej, Archaeologia Historica Polona, t. 16, s. 19-40.

2014 O ,dtugim wieku XIII” uwagi archeologa, Archaeologia Historica Polona, t. 22, s. 7-26.

Kamińska J.

1953 Grody wczesnośredniowieczne ziem Polski środkowej na tle osadnictwa, Łódź. Kłoczowski J.

2010 Wspólnoty zakonne w średniowiecznej Polsce, Lublin.

Kulesza M.

2001 Morfogeneza miast na obszarze Polski środkowej w okresie przedrozbiorowym. Dawne województwa łęczyckie i sieradzkie, Łódź.

Kurnatowska Z.

2000 Wczesnopiastowskie grody centralne. Podobieństwa i różnice, [w:] Gniezno

i Poznań w państwie pierwszych Piastów, red. A. Wójtowicz, Poznań, s. 9-31.

Marciniak-Kajzer A., Lechowicz Z.

2014 Góra św. Małgorzaty. Romańszczyzna koło Łęczycy, [w:] Średniowieczna architektura sakralna $w$ Polsce $w$ świetle najnowszych badań, red. T. Janiak, D. Stryniak, Gniezno, s. 109-124.

Między pólnoca a potudniem

1993 Między pótnoca a południem. Sieradzkie i Wieluńskie w późnym średniowieczu i czasach nowożytnych. Materiały z sesji naukowej w Kościerzynie koło Sieradza (4-6 grudnia 1991 r.), red. T. J. Horbacz, L. Kajzer, Sieradz.

Moździoch S.

1999 Miejsca centralne Polski wczesnopiastowskiej. Organizacja przestrzeni we wczesnym średniowieczu jako źródło poznania systemu społeczno-gospodarczego, [w:] Centrum i zaplecze we wczesnośredniowiecznej Europie Środkowej, Spotkania Bytomskie 3, red. S. Moździoch, Wrocław, s. 21-51.

Nowak T., Szymczak J.

1993 Obiekty obronne w Sieradzkiem i Wieluńskiem w świetle źródeł pisanych (do końca XVI w.), [w:] Między północa a południem, s. 81-95.

Piekalski J., Wachowski K.

2013 „Rodzime” $i$,obce” w krajobrazie kulturowym średniowiecznych ziem polskich, Archaeologia Historica Polona, t. 21, s. 127-169. 
Poczatki Łęczycy

2014 Początki Łęczycy, t. 1: Archeologia środowiskowa średniowiecznej Łęczycy. Przyroda-Gospodarka-Społeczeństwo; t. 2: Archeologia o początkach Łęczycy; t. 3: W kręgu historii i sztuki, red. R. Grygiel, T. Jurek, t. 1-3, Łódź.

Rajman J.

1996 Norbertanie polscy w XII wieku. Możni wobec ordinis novi, [w:] Społeczeństwo Polski średniowiecznej, t. 6, red. S. K. Kuczyński, Warszawa, s. 95-105.

Rębkowski M.

2001 Pierwsze lokacje miast w księstwie zachodniopomorskim. Przemiany przestrzenne $i$ kulturowe, Kołobrzeg.

Rosin R.

1963 Stownik historyczno-geograficzny ziemi wieluńskiej w średniowieczu, Warszawa.

1971 Miasta regionu łódzkiego. Próba periodyzacji dziejów, Region Łódzki. Studia i materiały, Łódź.

Sacrum pogańskie

2010 Sacrum pogańskie - sacrum chrześcijańskie. Kontynuacja miejsc kultu we wczesnośredniowiecznej Europie Środkowej, red. K. Bracha, C. Hadamik, Warszawa.

Sikora J.

2009 Ziemie centralnej Polski we wczesnym średniowieczu. Studium archeologiczno-osadnicze, Łódź.

2010 Miejsca sacrum pogańskiego i chrześcijańskiego oraz procesy chrystianizacji Polski Centralnej we wczesnym średniowieczu, [w:] Sacrum pogańskie, s. 253-265.

Sikora J., Trzciński Ł.

2013 Castrum Raczanz - przyczynek do obcych wpływów na XIII-wiecznym Pomorzu Wschodnim, Archaeologia Historica Polona, t. 21, s. 101-126.

Sikorski D.

2011 Kościół w Polsce za Mieszka i Bolestawa Chrobrego, Poznań.

2012a Poczatki Kościoła w Polsce, Poznań.

2012b Wczesnopiastowska architektura sakralna, Poznań.

Stasiak W., Trojan M.

2014 Gród tęczycki w okresie przedpiastowskim (faza I, koniec VIII-koniec $X$ wieku), [w:] Początki Łęczycy, t. 2, Łódź, s. 65-93.

Strzelczyk S.

2004 Europa środkowowschodnia w erudycji geograficznej średniowiecza, [w:]

Kolory i struktury średniowiecza, red. W. Fałkowski, Warszawa, s. 217-226.

Studia nad pradziejami

1975 Studia nad pradziejami Polski Środkowej, Prace i Materiały Muzeum Archeologicznego i Etnograficznego w Łodzi, Seria Archeologiczna, t. 22, red. K. Jażdżewski, Łódź. 
Trojan M.

2014 Grodzisko w Czerchowie na tle lokalnej sytuacji osadniczo-kulturowej we wczesnym średniowieczu, [w:] Początki Łęczycy, t. 2, s. 653-668.

Urbańczyk P.

2008 Trudne poczatki Polski, Wrocław.

2012 Mieszko Pierwszy tajemniczy, Toruń.

Zajączkowski S.

1966 Studia nad wielowioskowa własnościa szlachecka w Łęczyckiem i Sieradzkiem i jej rola w osadnictwie (od końca XIV do połowy XVI w.), Kwartalnik Historii Kultury Materialnej, t. 14, nr 2, s. 179-208.

1976 O przejściach przez Błota Łęczyckie w'średniowieczu, [w:] Ziemie i ludzie dawnej Polski. Studia z geografii historycznej, red. A. Galos, J. Janczak, Wrocław, s. 83-127.

\section{PRELUDE ON STRONGHOLD, CASTLE AND MONASTERY. A CENTRAL POLAND EXEMPLUM}

Summary

Historic Central Poland, i.e. the region located between the proper Greater Poland to the west and Mazovia to the east, between Kuyavia to the north and Lesser Poland to the south, because of its small surface and ambiguous 'transitory nature' can be regarded as a good training ground for research on the Middle Ages. For the historian the present Central Poland there are old lands, duchies, and then Łęczyca and Sieradz voivodeships; sometimes there was also included semi-autonomous Wielun Land. Already in the late Middle Ages it was the most easterly and southerly portion of the Greater Poland Province. The area of our interest was also located in a specific geographical context, i.e. on the border of two great landscape zones: the northern - lowland, where Łęczyca Land was, and the southern - the upland, which occupied half of Sieradz Land and whole Wielun Land.

This brief presentation of the relationship between strongholds, castles, monasteries and towns of Central Poland from the tribal period to the state of the last Piast encourages generalizations, especially in terms of observed chronological continuation and discontinuation, as well as the relationships between individual types of settlement structures. The cultural landscape determined initially by tribal and then by Piast strongholds outlined a net of important places, with remaining outside the classification, genuinely central cathedral Łęczyca. A clear swing brought initially the conquest of Central Paland by 'Polanie', and then formation of a network of castellany centres, delimiting regional political and settlement centres. The functioning of them has been affected by the transformation of the $13^{\text {th }}$ century, and they finally disappeared in the $14^{\text {th }}$ century, when in place of several such strongholds the state castles were built. This transformation generally determined the image of centres and other settlement structures in the region, perceptible up to the end of the Republic of Nobles.

Starting from the mid- $13^{\text {th }}$ century began to enter to this network defence and residential seats of fortified manor house nature, which location was marked by the distribution of large land property centres, and not only by knight estates. Also in the $13^{\text {th }}$ century 
widespread and the role of the most important settlement and market centres was somehow duplicated by towns incorporations. These were formed based on both proto-urban pre-incorporation structures, as wells as they had village origins or even were located in greenfield. Such apparently distant settlement categories - town and feudal estate with fortified manor house of the owner - in practice were not s. unfamiliar. The ideal of the late medieval feudal lord was in fact possessing a territorially compact estate with several villages, in the centre of which was the manor house and church, while potentially most profitable action was incorporation of such a village. This structure ensured security, faster than in rural areas turnover, and eventually it satisfied the need for own ancestral cemetery, which role in the earlier phases of the Middle Ages played family monastic foundations. 